\title{
Online Practicum Design (Praton) in Assisting Learning Process of Database Courses in the Information System Department, Universitas Terbuka, Indonesia
}

\author{
Andri Suryadi, Unggul Utan Sufandi and Dian Nurdiana \\ Study Program of Information System, Faculty of Sciences and Technology, Universitas Terbuka, Indonesia \\ Corresponding author mail: andri.suryadi@ecampus.ut.ac.id
}

\begin{abstract}
The development of technology is an inseparable part of human life. Through its development, technology furthermore produces various reliable tools to assist people in many ways. The technological applications can be in the forms of Google products such as Google Classroom, Google Form, and Google meet, and also other applications such as Zoom Cloud Meeting, Microsoft Teams intended to solve various kinds of problems including education field. These technological advancements are popularly used and are indeed very helpful in learning, but sometimes it can't be hindered that technological applications are not always in accordance with the needs. For example, the practicum learning process in the Information Systems Study Program, Faculty of Science and Technology, Universitas Terbuka, which has no practical application yet. This is because the existing applications are not in accordance with the learning process at the Universitas Terbuka. So, the solution that must be done is to develop an online practicum application (Praton) in the Information Systems Study Program, Faculty of Science and Technology, Universitas Terbuka. The process of developing a practicum application also cannot be done immediately, so at least there must be an application development design first. Application development design must go through several stages using a software development model. One of the models that can be used is the waterfall model with an object-based approach or commonly referred to as UML (Unified Modeling Language). The results of this software development design are in the form of a software design document and will be sent to a programmer to establish the application. With this application design, programmers will know more about the specifications of online practicum applications that suit the needs of learning process.
\end{abstract}

Keywords: Universitas Terbuka, Online Practicum, UML

\section{Introduction}

The technological development cannot be separated from human life activities. Technology has also become a reliable tool to solve various kinds of issue and education issue is to no exception (Chick et al., 2020; Ngafifi, 2014). Subsequent to the government policies related to Community Activity Restrictions (PPKM) (Hadi et al., 2021; Miharja et al., 2021). The learning activities are no longer conducted face-to-face but through virtual meeting using a network (online) (Sakina et al., 2020; Sukmanasa et al., 2020; Karns, 2005). Technological developments help and play an important role in today's learning methods. Some of the popular applications are Google application products (Google Classroom, Google Form, and Google meet), Zoom Cloud Meeting, Microsoft Teams (Singh and Awasthi, 2020; Gunawan et al., 2021; Chia et al., 2020). This application can be used easily because it provides a variety of service features that help users.

Despite that these popularly used technology apparatus are significantly helpful in learning process (Serhan 2020; Singhal, 2020; Syaharuddin et al., 2021; Trisnawan et al., 2019). It can't be denied that they have not always been in accordance with the learners' needs. One of the examples of this condition is in the practicum learning process of the Information Systems Study Program, Faculty of Science and Technology, Universitas Terbuka, which has no practical application yet. This happens due to the unsuitability of the existing applications in the learning process at the university.

A solution must therefore be sought to this issue by developing an online practicum application (Praton) in the Information Systems Study Program, Faculty of Science and Technology, Universitas Terbuka. However, the process of establishing a practicum application is not an overnight invention. There should be a design to this application 
development in advance of its establishment through several stages using a software development model. One of the models that can be used is the waterfall model with an object-based approach or commonly referred to as UML (Unified Modeling Language) (Nurfi et al., 2021; Zheng et al., 2014; Aggarwal, 2002).

The products of this software development design are in the form of a software design document which is planned to be sent to a programmer to create the application. With this application design, programmers would know more about the specifications of online practicum applications that suit their needs.

\section{Methodology}

The research flow applied in designing this application could be seen in Figure 1.

a. The Analysis of MSIM4206 BMP

The first step is to analyze the MSIM4206 Basic Materials (BMP) database. This BMP analysis is performed by choosing a practicum module that is in the subject matter. After the module selection was accomplished, the material analysis was carried out.

b. The Analysis of Practicum Material

The next step is to analyze the practical material. The analysis of this practical material is a simplification of the material that will be used in the application. After the material has been simplified, the system requirements analysis will then be carried out.

c. The Analysis of System Requirements

The next stage is the analysis of system requirements. At this stage, the analysis of the features that will be used in the system is conducted. The analysis of the system requirements is very important because it will determine whether the system is susceptible or not.

d. The Use Case Diagram

The use case diagram is a form of UML (Unified Modeling Language) diagram which is an overview of system interactions (Batra, 2008). Users or commonly called actors would interact with the functions that exist in the system .

e. The Activity Diagram

The Activity diagram is a description of the workflow in the system (Bastos and Ruiz, 2002). This activity diagram is created to explain the activities in the system and the flow of activities in the organization.

f. The Database Design

The database design is a basic foundation prepared to store and to process the data. If this database design is not optimal, the final result of the application won't also meet the need.

g. The Appearance Design

The view design is an overview of the appearance of the application that will be created. Through this overview, any programmers would understand the application better if the view design is well-made. This view design will support use case diagrams, activity diagrams, and database designs.

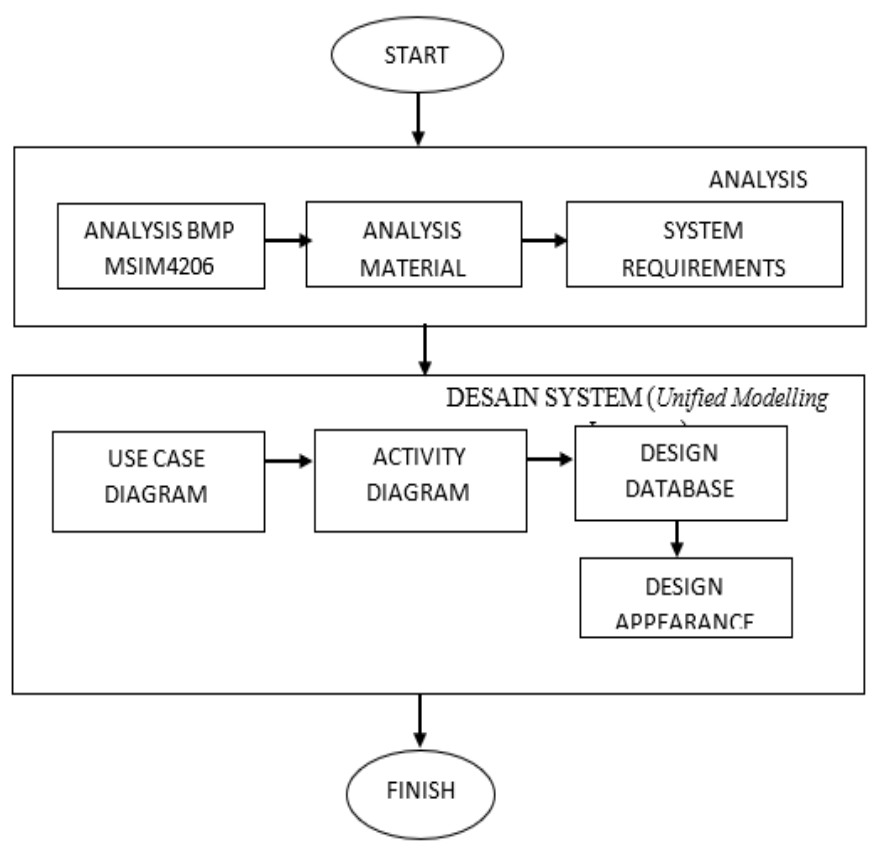

Figure 1. The Research flows 


\section{Results and Discussion}

\subsection{Analysis of the System}

1) The Analysis of Main Material MSIM4206

Teaching materials are learning tools functioning to assist the students' competencies achievement which has been determined in the curriculum (Ghavifekr and Rosdy, 2015)

The main materials functions as:

a. a guidance to boost students' motivation in learning

b. a lead for teacher to more easily control the students in learning process so that it becomes more effective and efficient.

c. a reference material for the researchers.

In the learning system of the Universitas Terbuka, teaching materials are the main learning resource for students. Teaching materials are specially designed so that students can study independently. There are several types of teaching materials, they are main teaching materials and supporting teaching materials. The main teaching materials are in the form of Basic Material Books (BMP), BMP Plus (BMP integrated with audio/video/graphics) and guidance in the form of audio CDs, audiographic CDs, video CDs, interactive CDs, computer-assisted BA, and online-based enrichment materials (MPBO). In addition to those printed and nonprinted teaching materials, UT also provides practical KIT for practical/practical courses. The teaching materials used are MSIM4206 Database teaching materials which can be seen in Figure 2.

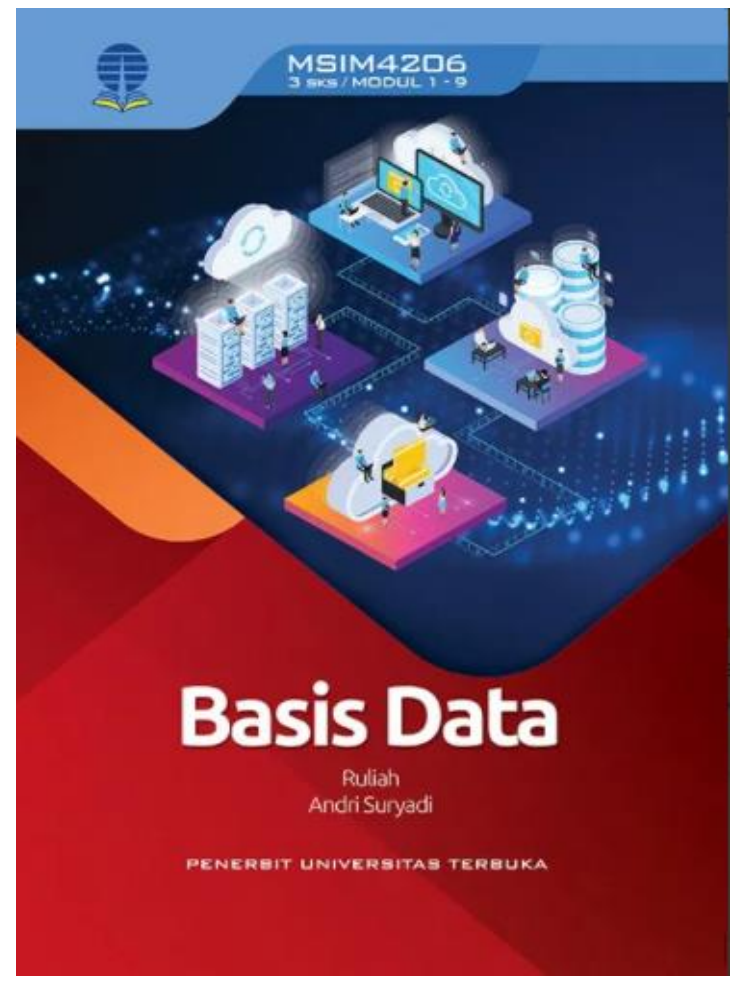

Figure 2. BMP MSIM4206

From these teaching materials, there is a practical material that will be established into the application. The practical material in MSIM4206 could be found in modules 3, 6, and 9.

2) The analysis of Practical Materials BMP MSIM4206

In the MSIM4206 Database teaching materials, the practicum process exists in modules 3, 6, and 9. The Table 1 show the list of the MSIM4206 Database modules.

From Table 1, it can be seen that the practicum exists in modules 3, 6, and 9. In module 3, Practicum of Making Entity Relationship Diagrams (ERD) is conducted using the Graph Editor application. In module 6 there is no special application used and it still uses a direct database. In module 9, the practicum uses a virtual box application. So based on the table above, the next analysis will only focus on module 6 . 
Table 1. The List of MSIM4206 Database Module Titles

\begin{tabular}{|c|c|c|c|}
\hline No & Module & & Module Title \\
\hline 1 & Module 1 & $:$ & $\begin{array}{l}\text { The Databases and The Systems of } \\
\text { Database }\end{array}$ \\
\hline 2 & Module 2 & $:$ & Data Models \\
\hline 3 & Module 3 & : & $\begin{array}{l}\text { Practicum of Making Entity } \\
\text { Relationship Diagram (ERD) }\end{array}$ \\
\hline 4 & Module 4 & : & Normalization \\
\hline 5 & Module 5 & $:$ & Structured Query Language (SQL) \\
\hline 6 & Module 6 & $:$ & $\begin{array}{l}\text { Practicum of Structured Query } \\
\text { Language (SQL) }\end{array}$ \\
\hline 7 & Module 7 & $:$ & $\begin{array}{l}\text { Transaction Management and Distributed } \\
\text { Database Concept }\end{array}$ \\
\hline 8 & Module 8 & : & Database Application Development \\
\hline 9 & Module 9 & $:$ & $\begin{array}{l}\text { Practicum of Transactions and } \\
\text { Distributed Database }\end{array}$ \\
\hline
\end{tabular}

\subsection{Design of System}

1. Use case diagram

The first system design is a use case diagram. The Use case diagram is an overview of the interaction between the user and the system. The use case diagram comprises the actors or users, system constraints, and use cases. The use case diagram can be seen in Figure 3.

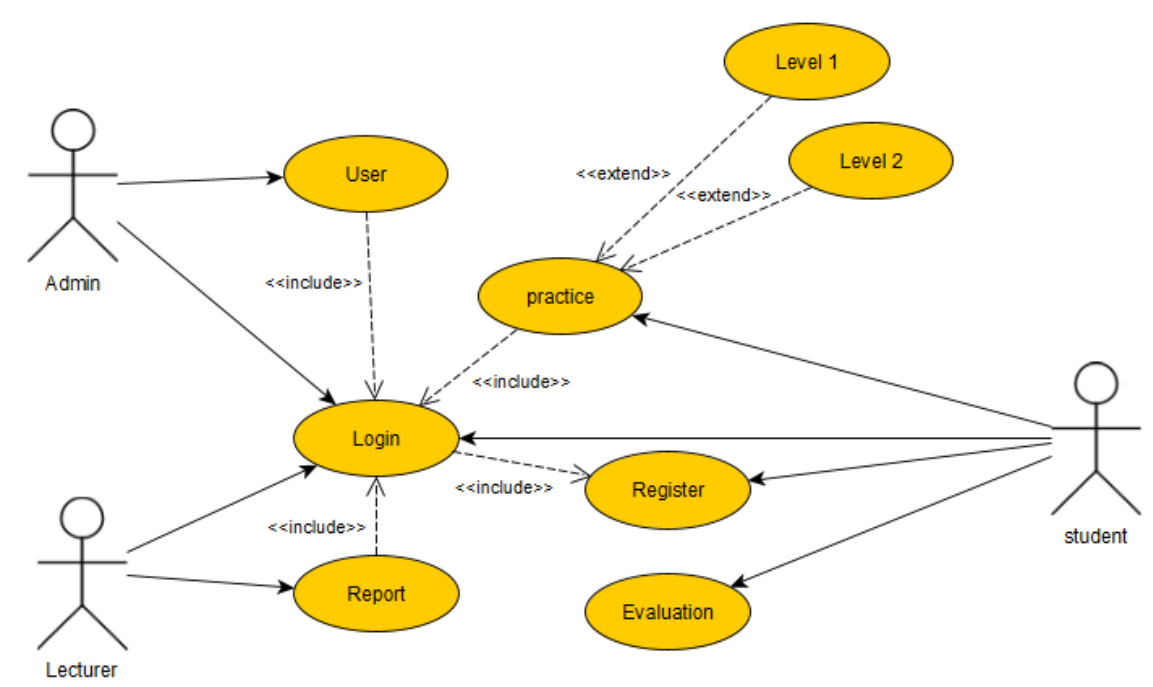

Figure 3. Use case diagram

There are 3 actors that interact with the system, they are admin, lecturer, and students. Each actor must first login prior to the entrance to the system. The admin actor interacts with the login case and the users, which means that the admin can manage the registered users. Furthermore, lecturer actors interact login and report. Then student actors interact with login, register, evaluation, and practicum. In the practical use case, there are 3 use cases (extend = expansion), they are level 1 and level 2.

2. Activity diagram

In the next design is activity diagrams. The activity diagram is found and occurs in the system. The activity diagram for this system is shown in Figure 4. 


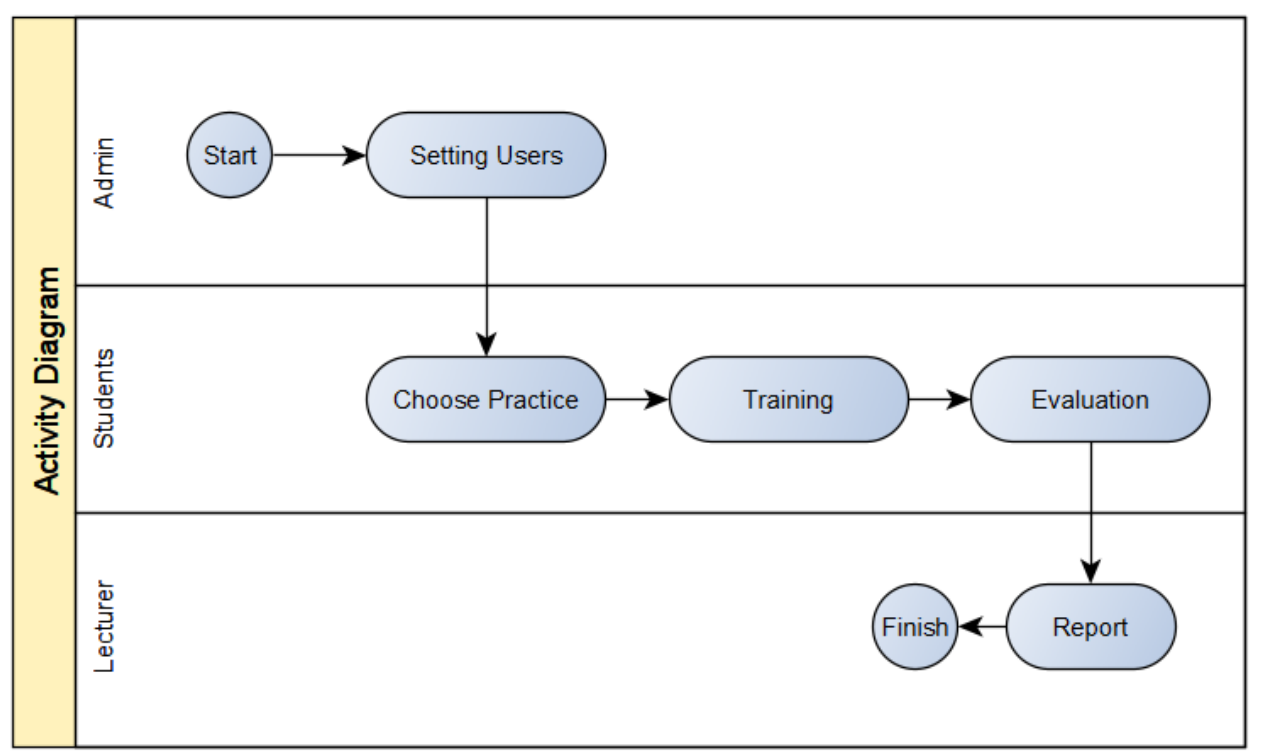

Figure 4. Activity diagram

The activity starts from the admin since the admin is responsible of doing user settings. After the completion in settings, the student chooses the practicum menu, then to practice tabulation, and ends with the evaluation menu. The results of the evaluation can only be seen by the lecturer.

3. The Database designs

The next systematic design is the database design. There are 4 tables provided in this system. The tables can be seen in Figure 5.

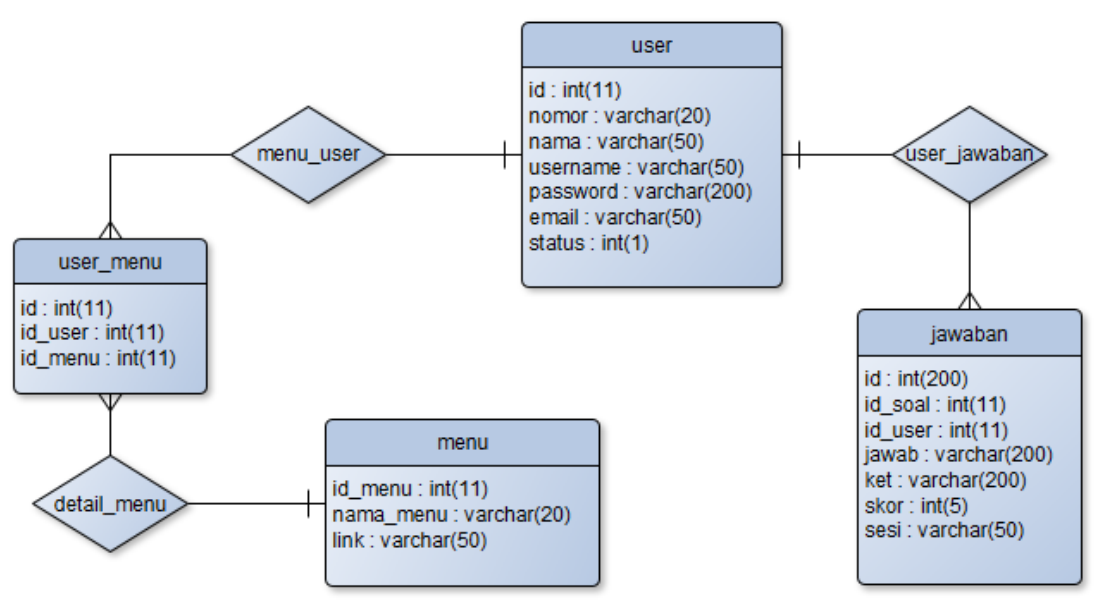

Figure 5. The design of the Database

The users' table consists of id, number, name, username, password, email, and status. Then the user menu table consists of id, id_user, and id_menu. Furthermore, the menu table consists of id_menu, menu_name, and links. Then the answer table consists of id, id_question, id_user, answer, note, score, session.

4. The Appearance Design.

The final system design is the appearance design. In this view, the description of the appearance design is shown in Figure 6.

a. The Front page views

The front-page view is the first view which is accessed by the users. The display of the front page can be seen in the following image: 


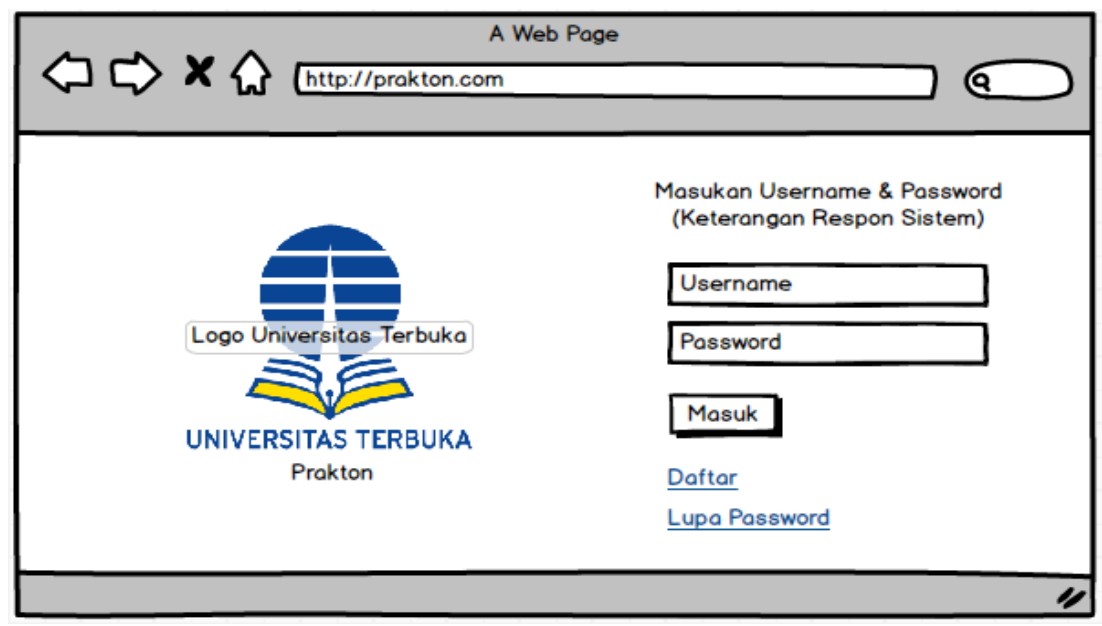

Figure 6. Front page view

b. Practicum page view

The next view is the practical page. This practicum page appearance can be accessed only by students. The design image of the practicum page view can be seen in Figure 7.

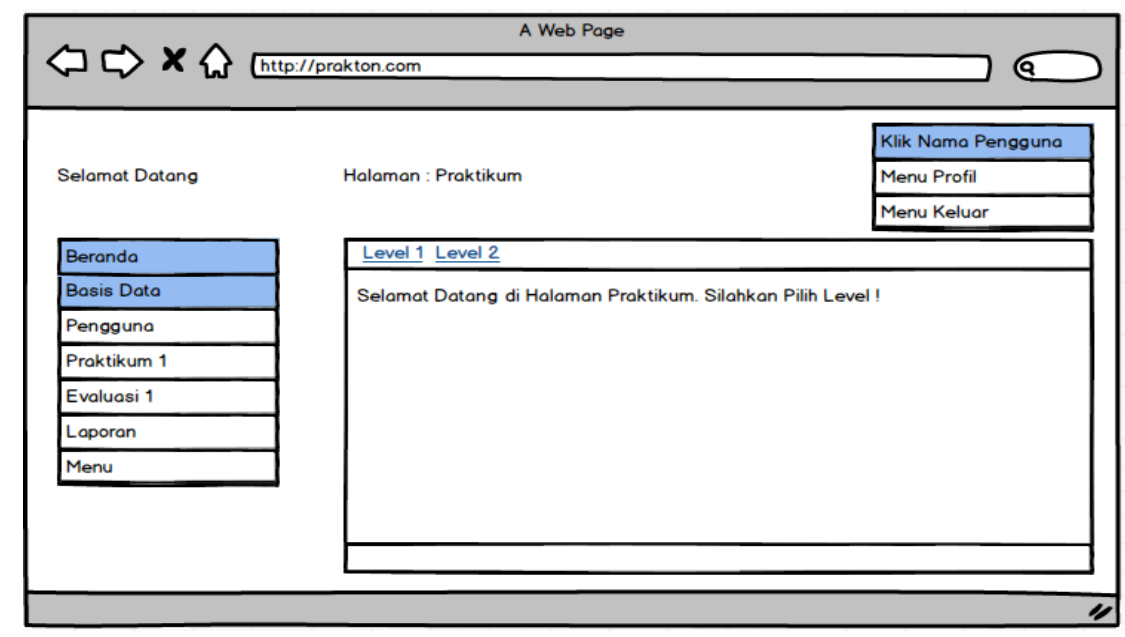

Figure 7. Practical view

The practicum page contains 2 menus, they are level 1 and level 2. More detail view of each view can be seen in Figure 8.

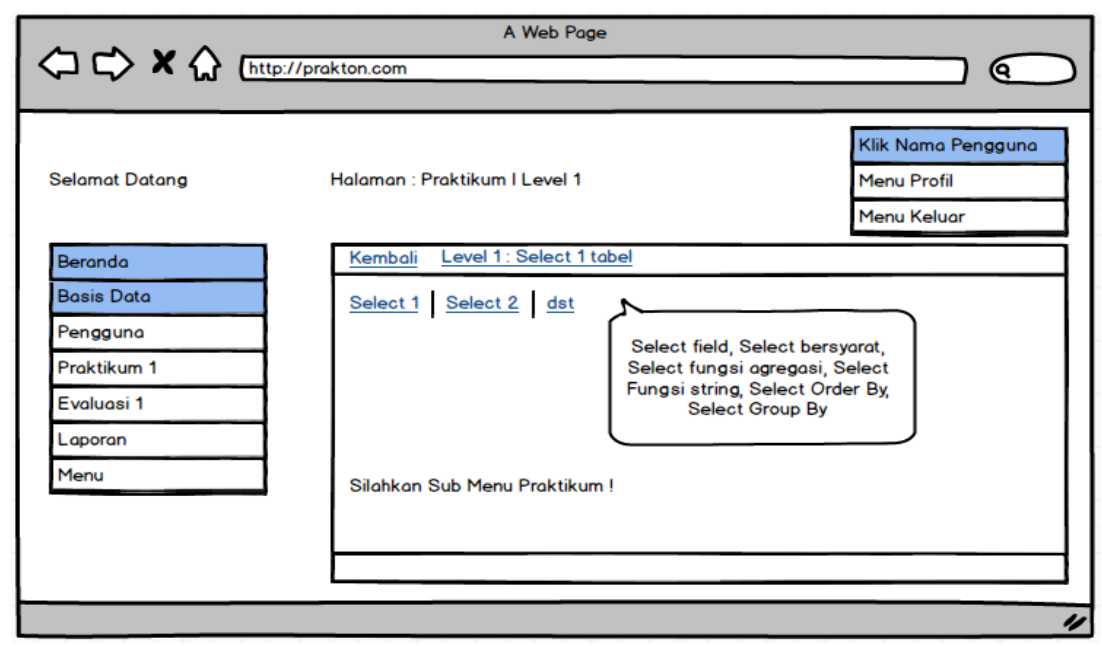

Figure 8. Page view level 1 
The page view of this level contains a sub menu 'BACK' based on the material that will be given to the students. To see the material illustration, press select 1 and select 2 and so on. If one of the materials is selected, it can be seen in Figure 9.

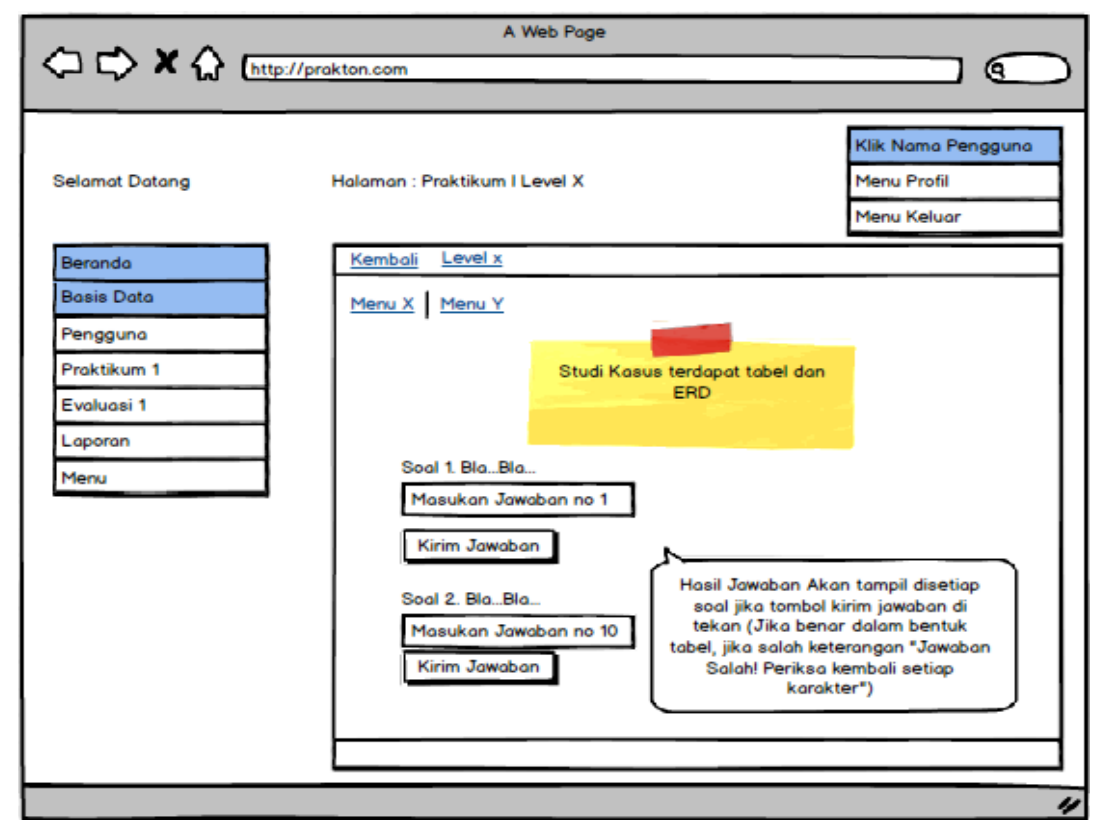

Figure 9. Material page view

In the material page view, exercises are available which can be used by students to find examples of the exercises based on the material. In this section, answers to the exercises are provided so the students can check their own work.

\section{c. Evaluation page view}

On this evaluation page, students can evaluate themselves through 10 case study questions of which answers can be directly checked and stored by the system. Students can do more than one evaluation and the score are stored in the system. The design of this evaluation can be seen in Figure 10.

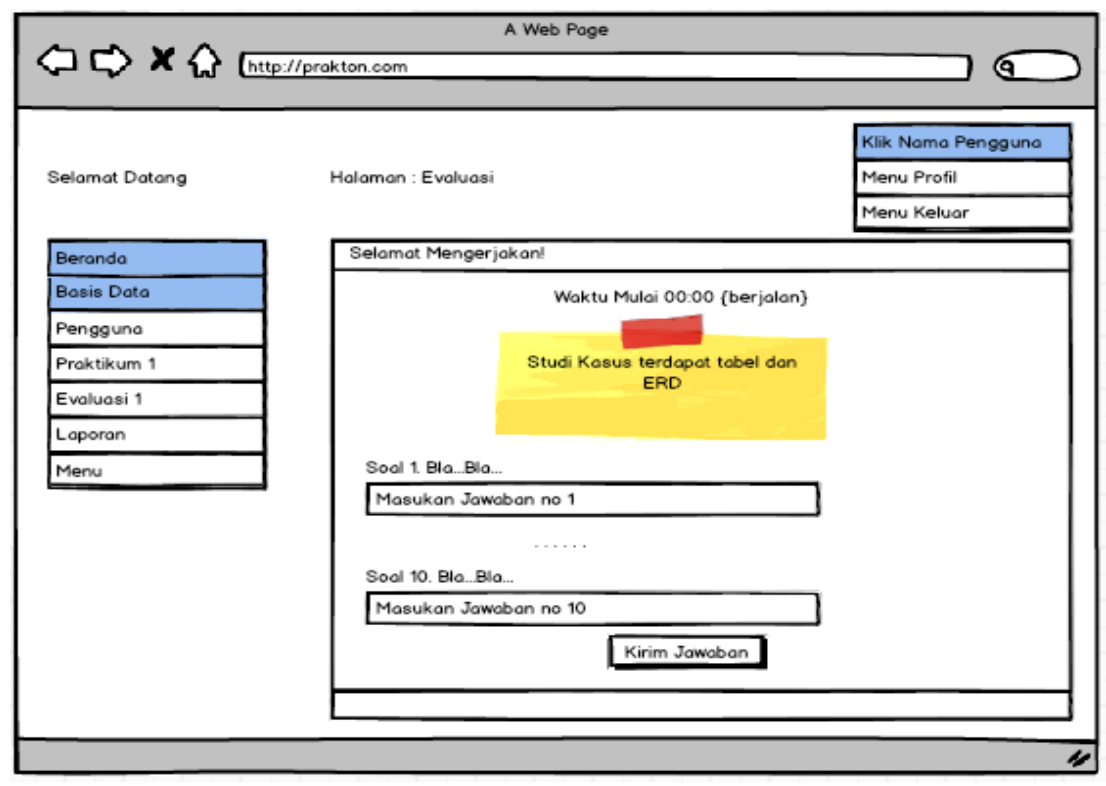

Figure 10. Evaluation page view

Then after the completion of the evaluation, the results can be seen in the value history by the user can be seen in Figure 11. This history page is the students 'scores history obtained after conducting several evaluations. 


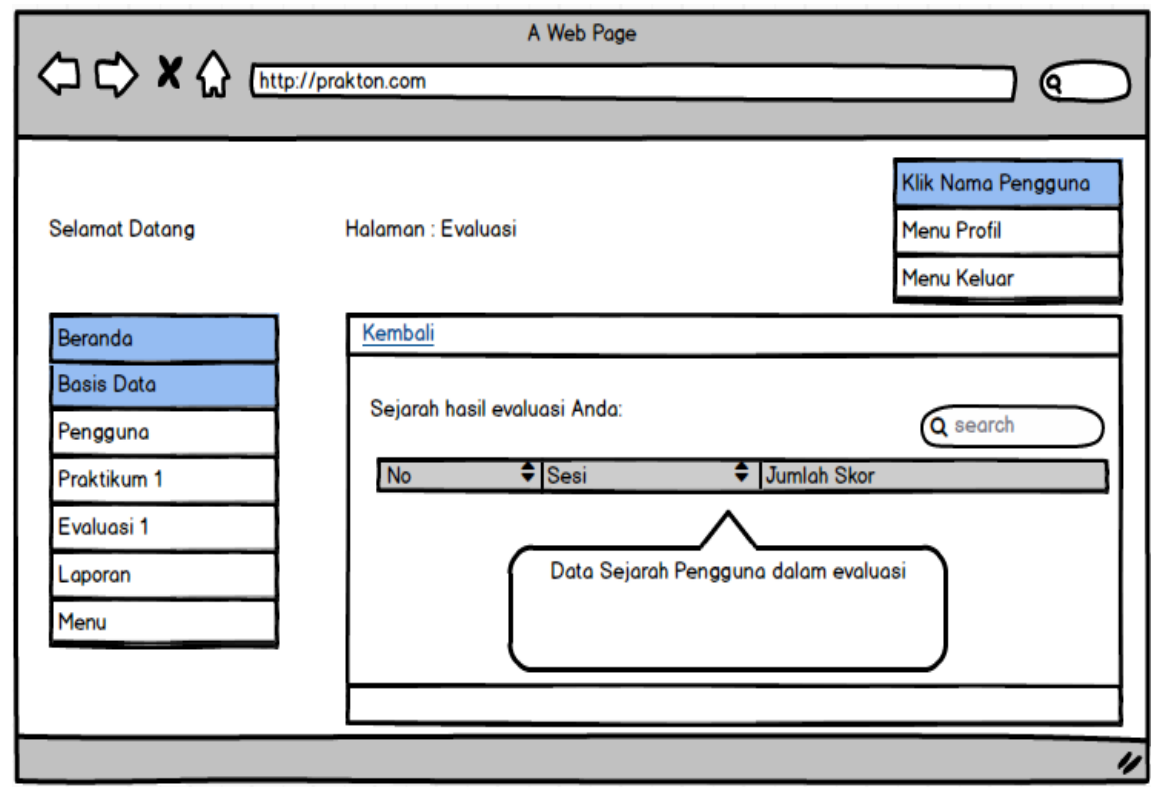

Figure 11. score history page view

\section{Conclussion}

In this paper, we have developed an online practicum application (Praton) in the Information Systems Study Program, Faculty of Science and Technology, Universitas Terbuka. The results of the analysis produce a material existing in the MSIM4206 BMP Database in module 6, it is Structured Query Language (SQL) Practicum. Furthermore, the design stage is made using Unified Modeling Language (UML) to produce use case diagrams, activity diagrams, database designs, and view/appearance designs. After the design phase is complete, the programmer is processed to be converted into a programming language.

\section{References}

Bastos, R. M., \& Ruiz, D. D. A. (2002, January). Extending UML activity diagram for workflow modeling in production systems. In Proceedings of the 35th Annual Hawaii International Conference on System Sciences (pp. 3786-3795). IEEE.

Batra, D. (2008). Unified modeling language (UML) topics: the past, the problems, and the prospects. Journal of Database Management, 19(1), 1-20.

Chia, C. K., Ghavifekr, S., \& Razak, A. Z. A. (2020). Online interview tools for qualitative data collection during Covid-19 pandemic; Riview of web conferencing platforms' functionality. Malaysian Journal of Qualitative Research, 7(1), 95-106.

Chick, R. C., Clifton, G. T., Peace, K. M., Propper, B. W., Hale, D. F., Alseidi, A. A., \& Vreeland, T. J. (2020). Using technology to maintain the education of residents during the COVID-19 pandemic. Journal of surgical education, 77(4), 729-732.

Ghavifekr, S., \& Rosdy, W. A. W. (2015). Teaching and learning with technology: Effectiveness of ICT integration in schools. International Journal of Research in Education and Science, 1(2), 175-191.

Gunawan, G., Kristiawan, M., Risdianto, E., \& Monicha, R. E. (2021). Application of the Zoom Meeting Application in Online Learning During the Pandemic. Education Quarterly Reviews, 4(2), 26-32.

Hadi, A. J., Riman, E. Y., Ahmad, H., Nur, N. H., \& Antoni, A. (2021). Diet Behavior During Covid-19 Period the Enforcement of Community Activity Restrictions. Pancasakti Journal Of Public Health Science And Research, 1(2), 128-132.

Miharja, M., Salim, E., Nachrawi, G., Putranto, R. D., \& Hendrawan, A. (2021). Implementation of Emergency Public Activity Restrictions (PPKM) in Accordance With Human Rights and Pancasila Principles. Budapest International Research and Critics Institute (BIRCI-Journal): Humanities and Social Sciences, 4(3), 6855-6866.

Ngafifi, M. (2014). Advances in Technology and Patterns of Human Life in Socio-Cultural Perspective. Kemajuan Teknol. dan Pola Hidup Mns, 2(1), 33-47. 
Nurfi, N., Syahputra, E. R., \& Lubis, F. R. (2021). Goods Inventory Card System Design Using The Unified Modeling Language (UML) of Department Libraries and Archives at Medan City. Journal of Computer Science, Information Technology and Telecommunication Engineering, 2(2), 217-225.

Sakina, R., Kulsum, E. M., \& Uyun, A. S. (2020). Integrating Technologies in the New Normal: A Study of Blended Learning. International Journal of Quantitative Research and Modeling, 1(4), 181-193.

Serhan, D. (2020). Transitioning from face-to-face to remote learning: Students' attitudes and perceptions of using Zoom during COVID-19 pandemic. International Journal of Technology in Education and Science, 4(4), 335-342.

Singhal, M. K. (2020). Facilitating virtual medicinal chemistry active learning assignments using advanced Zoom features during COVID-19 campus closure. Journal of Chemical Education, 97(9), 2711-2714.

Singh, R., \& Awasthi, S. (2020). Updated Comparative Analysis on Video Conferencing Platforms-Zoom, Google Meet, Microsoft Teams, WebEx Teams and GoToMeetings. EasyChair: The World for Scientists, 1-9.

Sukmanasa, E., Novita, L., \& Maesya, A. (2020). Training in Making Powtoon-Based Learning Media in Education 4.0. International Journal of Business, Economics, and Social Development, 1(2), 72-80.

Syaharuddin, S., Husain, H., Herianto, H., \& Jusmiana, A. (2021). The effectiveness of advance organiser learning model assisted by Zoom Meeting application. Cypriot Journal of Educational Sciences, 16(3), 952-966.

Trisnawan, Sanjaya, W. S. M., Sambas, A., Jannah, M., Rahayu, D. S., Mamat, M., \& Mohamed, M. A. (2019). Design of 4 Dof Robot ARM Based on Adaptive Neuro-Fuzzy (ANFIS) using Vision in Detecting Color Objects. International Journal of Recent Technology and Engineering, 8(2S7), 224-227.

Zheng, J., Feng, Y., \& Zhao, Y. (2014). A unified modeling language-based design and application for a library management information system. Cybern. Inf. Technol, 14(5), 129-144. 